\title{
Agnikarma (therapeutic heat burn) an unique approach in the management of vatakantaka w.s.r. to plantar fasciitis- A single Case Report Riddhi Ganatra $^{1}$, Manisha Kapadiya ${ }^{2 *}$, TS Dudhamal ${ }^{3}$ \\ ${ }^{1} \mathrm{MS}$ (Scholar), ${ }^{2} \mathrm{PhD}$ (Scholar), ${ }^{3}$ Associate Professor \& I/C HoD,
}

Dept. of Shalya Tantra, Institute of Teaching and Research in Ayurveda (INI), Jamnagar, Gujarat, India

\begin{abstract}
Heel pain is most common condition now days and the ratio of occurrence observed is 1 out of 10 people suffered once during their life period. There are so many conditions causing heel pain among that plantar fasciitis is one which is having high prevalence rate. In Ayurveda Plantar fasciitis can be corelated with Vatakantaka. Walking on uneven surface and repeated injury may leads to Vata prakopa due to that it develops pricking type of pain like thorn in heel region and ultimately leads to Vatakantaka. This is the small evidence to support traditional treatment modalities to describe for management of Vatakantaka (planter fasciitis). A 47 year old male patient complaining of pain in right heel region for 5 months along with difficulty in walking after awakening from bed at morning. Then patient was treated in outdoor patient department with 4 successive sittings of bindu dagdha Agnikarma at posterior medial side of right heel region in 7 days interval along with Rasna Saptaka Kwatha $20 \mathrm{ml}$ empty stomach orally two times a day for one month. After one month of treatment, patient got complete relief in pain and stiffness.
\end{abstract}

Key Words: Agnikarma, Plantar fasciitis, Vatakantaka.

Received: 17.02 .2021

Revised: 24.03 .2021

Accepted: 29.03.2021

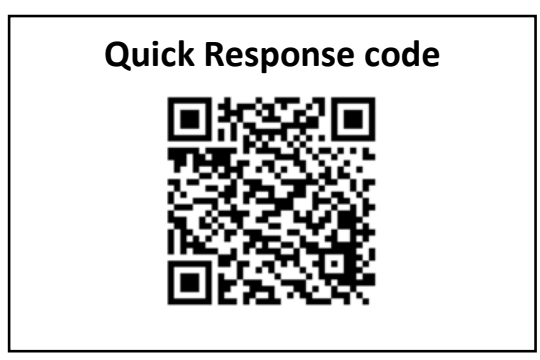

*CORRESPONDING AUTHOR:

Dr. Manisha Kapadiya

$\mathrm{PhD}$ (Scholar), Dept. of Shalya Tantra,

Institute of Teaching and Research in Ayurveda

(INI), Jamnagar

Email: manisha.kapadiya15@gmail.com 


\section{Introduction:}

Heel pain is a frequently encountered entity now days. There are so many disorders causing heel pain among that most prevalent condition is plantar fasciitis. It is defined as sharp pain on the plantar surface of the heel and most common cause of posterior heel pain. ${ }^{[1]}$ Pain usually occurs at morning after awakening from bed or after some period of rest this is typical presentation in plantar fasciitis. The incidence of this condition is estimated that 1 out of 10 people suffered once with this condition during their life time period. Prevalence of this condition usually manifested in middle age group between 45 to 64 years. ${ }^{[2]}$ The exact cause of plantar fasciitis is unknown but it is believed that most cases result from overuse stress. The probable risk factors of plantar fasciitis include trauma to heel, excessive running, obesity and occupation requiring prolonged standing. In contemporary science treatment of plantar fasciitis include Analgesics, NSAIDs (Nonsteroidal anti-inflammatory drugs), Extracorporeal Shock Wave Therapy, Iontophoresis, Laser therapy, Local infiltration of corticosteroids and lastly if all these treatment failed then last option remain is surgical splitting of plantar fascia. ${ }^{[3]}$ However, all these treatments are time taking, expensive along with their own limitations.

In Ayurveda plantar fasciitis can be corelated with the Vatakantaka (Painful heel) which is described by Acharya Sushruta under the heading of Vatavyadhi (Disorder due to Vata). As Acharya explained Vatakantaka occurs due to excessive standing or walking on uneven surface resulting in to vitiation of Vata which leads to condition called Vatakantaka. [4] Vatakantaka is a AsthiSnayu Sandhigat Vata. There are various types of treatment methods explained by different Acharya in context of Vatavyadhi like Shaman, Snehan (Unctuousness), Swedan (Sudation), Raktamokshan (Bloodletting), Agnikarma and many more. Among them, Agnikarma has paramount importance in treating Vataj disorders. Rasna Saptaka Kwatha mentioned in Vatarogadhikar which have Shothahar (Substance reducing inflammation), Vatanulomana (Proper functioning of Vata), Amapachaka properties.

\section{Case Report:}

A 47 year-old male patient came to OPD of Shalya Tantra Department with chief complaints pain in right heel region for 5 months. Pain and stiffness were worst after weaking up from bed at morning and cause difficulty in walking. The patient was apparently normal before 5 months. Patient gradually developed pain and stiffness in right heel. The body weight of patient was $91 \mathrm{~kg}$. Patient reported history of trauma by stone to right heel before 6 months. He visited Government hospital and was treated with NSAIDs and physiotherapy for 3 months but didn't get complete relief from symptoms. No any other significant past history of Hypertension, Diabetes mellites, Tuberculosis or any chronic illness. On inspection, there was no evidence of redness or swelling found on right heel. Grade III tenderness (Dr Frank Painter's grading) found at posteromedial aspect of right heel on palpation. Windlass test was positive in right side of foot. 
There was raised ESR (Erythrocyte Sedimentation Rate) $26 \mathrm{~mm} / \mathrm{hr}$ noted and $\mathrm{X}$-ray of right foot anterio-posterior and lateral view demonstrates normal findings. On the basis of history and clinical examination of patient was diagnosed with Vatakantaka (Plantar fasciitis).

\section{Treatment Plan}

\section{Systemic medication:}

Patient was treated with Rasna Saptak Kwatha $20 \mathrm{ml}$ orally before meal for one month.

\section{Local treatment: Method of Agnikarma}

Informed written consent was taken from patient before starting of procedure and treatment protocol explained in briefly. In supine position, located maximum tender point in right side of heel region and marked with pen. Cleaning of local part with Triphala Kashaya done then it was wiped with dry sterile gauze. 10-15 Samyak Bindu Dagdha (fig.2) made with red hot Panchdhatu Shalaka (fig. 1) at right heel. Simultaneously aloe vera pulp (fig. 3) applied to minimize burning sensation then dusting of Haridra (Curcuma longa Linn.) powder (fig. 4) done. Patient was advised to avoid water contacts for 24 hours and application of cow ghee at local part twice a day. This same procedure was repeated after 7 days. Total 4 sittings $\left(0,7^{\text {th }}, 14^{\text {th }}\right.$ and $21^{\text {st }}$ day $)$ of Agnikarma done.

\section{Observations and Result:}

Special scoring pattern was adopted to observe relief in sign and symptoms (Table $1 \&$ Table 2). Therapeutic assessment of pain was observed (fig. 5)

\section{Follow Up:}

After completion of one month treatment protocol patient was assessed for any recurrence of symptoms. Patient got complete from symptoms and there was no any recurrence of symptoms in 2 months of follow up period.

Table 1: Scoring pattern of sign and symptoms

\begin{tabular}{|l|l|l|l|l|}
\hline $\begin{array}{l}\text { Symptoms } \\
\text { and signs }\end{array}$ & Grading & \multicolumn{4}{|l|}{} \\
\hline & 0 & 1 & 2 & 3 \\
\hline Pain in heel & No pain & $\begin{array}{l}\text { Mild pain } \\
\text { (Not disturbing } \\
\text { daily routine } \\
\text { activity and pain } \\
\text { only during } \\
\text { morning hours) }\end{array}$ & $\begin{array}{l}\text { Distressing pain } \\
\text { (Continuous pain in } \\
\text { the morning hours } \\
\text { and } \\
\text { walking after rest) }\end{array}$ & $\begin{array}{l}\text { Severe } \\
\text { excruciating pain } \\
\text { (Pain throughout } \\
\text { the } \\
\text { day and disturbing } \\
\text { daily routine) }\end{array}$ \\
\hline Stiffness & No stiffness & Mild stiffness & Moderate stiffness & Severe stiffness \\
\hline Tenderness & No tenderness & $\begin{array}{l}\text { Mild tenderness } \\
\text { (Pain on deep } \\
\text { pressure) }\end{array}$ & $\begin{array}{l}\text { Moderate } \\
\text { tenderness } \\
\text { (Pain on slight } \\
\text { pressure) }\end{array}$ & $\begin{array}{l}\text { Severe tenderness } \\
\text { (Pain on touch) }\end{array}$ \\
\hline
\end{tabular}


Table 2: Assessment of Result:

\begin{tabular}{|l|l|l|l|l|l|l|}
\hline Assessment criteria & $\begin{array}{l}\text { Before } \\
\text { treatment }\end{array}$ & $\begin{array}{l}\text { After } \\
\text { sitting }\end{array}$ & $\mathbf{1}^{\text {st }}$ & $\begin{array}{l}\text { After } \\
\text { sitting }\end{array}$ & $\begin{array}{l}\text { After } \\
\text { sitting }\end{array}$ & $\begin{array}{l}\text { After } \mathbf{4}^{\text {th }} \\
\text { sitting }\end{array}$ \\
\hline Pain in heel & 3 & 2 & 1 & 0 & 0 \\
\hline Stiffness & 3 & 2 & 2 & 1 & 0 \\
\hline Tenderness & 3 & 2 & 2 & 1 & 0 \\
\hline
\end{tabular}

\section{Clinical images:}

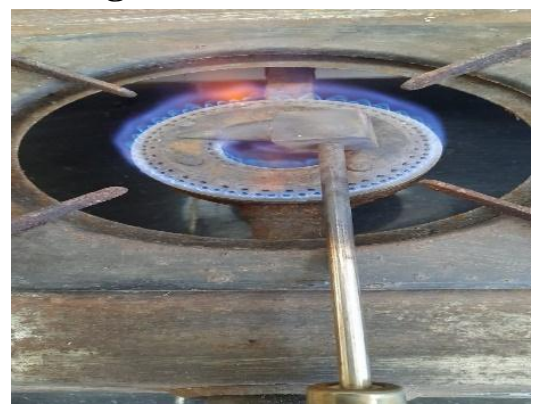

Fig 1: Red hot Shalaka

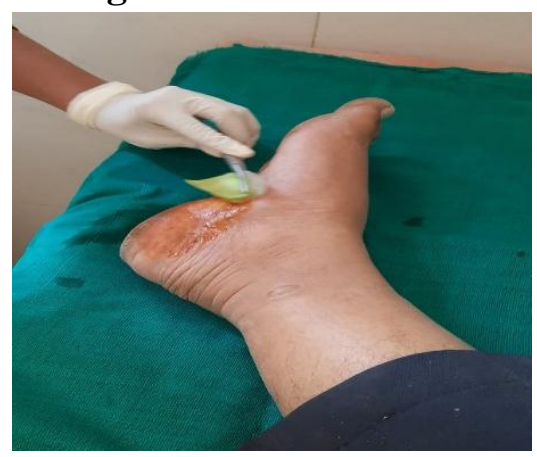

Fig 3: Application of Aloe vera

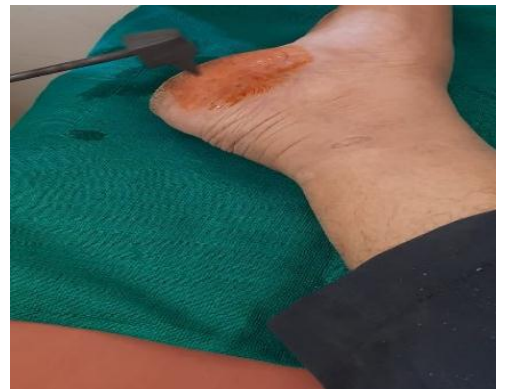

Fig 2: Bindu Dagdha

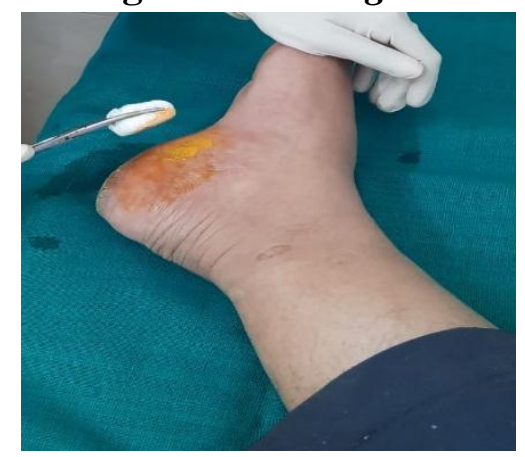

Fig 4: Application of Haridra

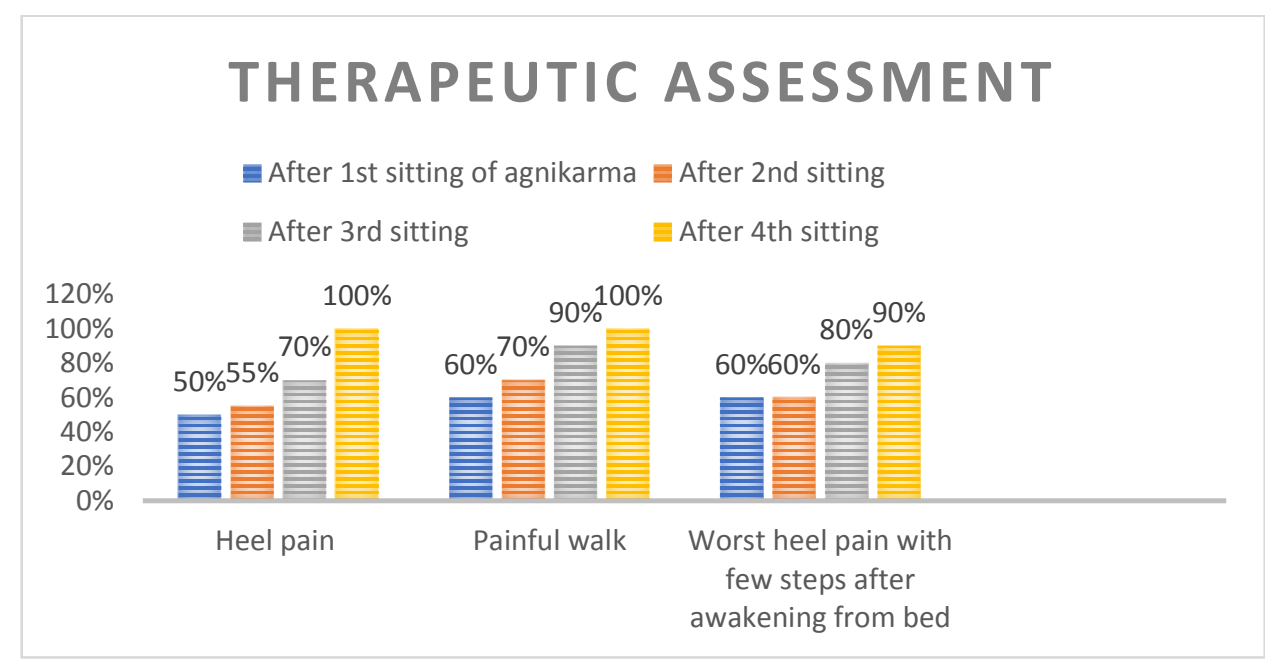

Fig- 5: Therapeutic assessment of pain 


\section{Discussion:}

Among para-surgical procedures Agnikarma has paramount importance from ancient time as it cures instantly with less recurrence of disease. In Yogratnakar Agnikarma specifically indicated in the treatment of Vatakantaka. [5] In case of Dhatu Kshaya Janya condition application of Ushna (Hot), Tiksna (Sharp), Suksma (Minute), Ashukari Guna of Agnikarma to Asthi Sandhi through Twaka Dhatu leads to direct impact on Marmaasthi Sandhi Gata Mahabhutagni which result in to stoppage of Dhatu Kshaya process by establishing Agni Samatva and normalize function of Vata dosha which eliminates Shotha, Shool and Stambha.

In this patient cause of plantar fasciitis might be due to past history of trauma which leads to tear in plantar fascia and further it resulting in to development of plantar fasciitis. As patient was obese (91 $\mathrm{kg}$ ) and having prolong standing work the weight bearing on the heal region leads to provoke the pain and inflammation at plantar fascia.

The therapeutic heat leads to vasodilatation by thus it increasing blood circulation at local site. This increased blood circulation flushes away the pain producing substances and metabolic waste products from that site as well as provides auto immune response by virtue of chemical transportation and bringing proper nutrition to tissue. ${ }^{[6]}$ In addition to therapeutic heat increases temperature at the applied site which reduces nerve reflexes resulting of relaxation of muscle thereby causing a reduction of stiffness.
Rasna Saptak Kwatha regulates Vata Dosha and also it does Aam Pachan in body. Some researches reveled that it acts as anti-inflammatory and analgesics. Ingredients like Rasna (Pluchea lanceolata C.B Clarke), Guduchi (Tinospora cordifolia (Thunb. Miers), Punarnava (Boerhavia diffusa L. nom. cons.), Eranda (Ricinus communis L.), Aragvadha (Cassia fistula L.) and Sunthi (Zingiber officinale Roscoe) have antioxidant role. ${ }^{[7]}$ By virtue of this action Rasna Saptak Kwatha also helps to reduce pain and other symptoms in Vatakantaka.

\section{Conclusion:}

A single case report demonstrates that Agnikarma is safe and cost effective OPD based procedure to manage Vatakantaka with orally Rasna Saptaka Kwatha.

\section{Limitation of study:}

The study would be more scientific if thickness of planter fascia measured before and after treatment. As this is single case study so for its scientific validation the same protocol may be tried in more number of cases of Vatakantaka.

\section{Consent of patients:}

Informed written consent of patient was taken for procedure and publication of the images without disclosing the identity of patient.

\section{Acknowledgement:}

I express my sincere gratitude to respected Dr. Anup Thakar, Director ITRA Jamnagar to give permission to conduct research and providing all facilities in Agnikarma unit of Shalya Tantra. 


\section{References:}

1. Ebnezar J, Rakesh J. textbook of orthopedic. Regional conditions of lower limb, Chapter 32. $5^{\text {th }}$ editon. Jaypee publication. 2017. p-428.

2. Riddle DL, Schappert SM. Volume of ambulatory care visits and patterns of care for patients diagnosed with plantar fasciitis: a national study of medical doctors. Foot Ankle Int. 2004; 25(5): 303-310.

3. Ebnezar J, Rakesh J. textbook of orthopaedic. Regional conditions of lower limb, Chapter 32. $5^{\text {th }}$ edition. Jaypee publication. 2017. p-429.

4. Shastri A. Hindi commentator of Sushruta Samhita Nidana sthana, Vatavyadhinidanam 1/79, Chaukhambha Sanskrit sansthan, Varanasi. Reprint ed. 2014 p-304.

5. Tripathi I, Hindi commentator of Yogratnakar Chikitsasthan Vatavyadhi chikitsa Verse.10 Chaukhamba publications Varanasi. Reprint ed. 2020 p-524.
6. McLean DA. The use of cold and superficial heat in the treatment of soft tissue injuries. $\mathrm{Br} \quad \mathrm{J}$ Sports Med.1989;23(1): p-53-4

7. Shruti P, Chaudhary AK. A review on Rasna Saptak Kwath: An Ayurvedic polyherbal formulation for arthritis. Int. J. Res. Ayurveda Pharm. 2017;8(Supp 1):4-11.

Conflict of interest: Author declares that there is no conflict of interest.

Guarantor: Corresponding author is guarantor of this article and its contents.

\section{Source of support: None}

\section{How to cite this article:}

Ganatra R, Kapadiya M, Dudhamal TS. Agnikarma (therapeutic heat burn) an unique approach in the management of vatakantaka w.s.r. to plantar fasciitis- A single Case report. Int. J. AYUSH CaRe. 2021; 5(1):30-35. 